\title{
Isolation, Identification and Screening for Nitrogen Fixing Activities by Azotobacter chroococcum Isolated from Soil of Keffi, Nigeria as Agent for Bio-fertilizer Production
}

\author{
Ishaya Isa Obele ${ }^{1,}$, , Makut Makwin Danladi ${ }^{1}$, Ombugadu Akwashiki ${ }^{2}$, Gabriel Owuna ${ }^{1}$, \\ Odonye Enoch Peter ${ }^{1}$, Smart Obiekezie ${ }^{1}$, Tsaku Paul ${ }^{1}$, Ekeleme Ikke Kenneth ${ }^{1}$, \\ Akirinola-Akinyemi Olokunle ${ }^{3}$ \\ ${ }^{1}$ Department of Microbiology, Faculty of Natural and Applied Science, Nasarawa State University, Nasarawa, Nigeria \\ ${ }^{2}$ Department of Zoology, Faculty of Science, Federal University Lafia, Nasarawa, Nigeria \\ ${ }^{3}$ Federal Institutes of Industrial Research, Oshodi Lagos, Nigeria
}

Email address:

ishayaisaobele@gmail.com (I. I. Obele)

${ }^{*}$ Corresponding author

\section{To cite this article:}

Ishaya Isa Obele, Makut Makwin Danladi, Ombugadu Akwashiki, Gabriel Owuna, Odonye Enoch Peter, Smart Obiekezie, Tsaku Paul, Ekeleme Ikke Kenneth, Akirinola Akinyemi Olokunle. Isolation, Identification and Screening for Nitrogen Fixing Activities by Azotobacter chroococcum Isolated from Soil of Keffi, Nigeria as Agent for Bio-fertilizer Production. Frontiers in Environmental Microbiology. Vol. 5, No. 3, 2019, pp. 70-76. doi: 10.11648/j.fem.20190503.11

Received: April 9, 2019; Accepted: May 27, 2019; Published: August 5, 2019

\begin{abstract}
Free living nitrogen fixing bacteria are those that lives freely on rhizosphere of a young growing plant or those living in a close association with root of plants (Rhizobacteria) but not symbiotically. In most tropical soil, Nitrogen and other essential nutrients element are the most limiting nutrients which deficiencies could lead to slow growth and reduced crop production. Free living nitrogen fixing bacteria has the potential of secreting nitrogenase enzymes and produces organic acids such as glycolic, acetic, malic, succunic acids which fix atmospheric nitrogen directly into the soil for plants growth and development. To this end, the study on isolation, identification and screening of Azotobacter chroococcum from soil of Keffi, Nasarawa State, Nigeria was carried out from May to September 2018. Soil samples were collected from eight different locations and Azotobacter strains were isolated and identified using standard microbiological methods. The 16SrRNA gene sequence analysis of the strain showed maximum similarity of $96 \%$ with Azotobacter chroococcum of the reference type strain deposited in RDP Gen Bank database. Azotobacter strains isolated from four different locations showed coloured zone ranging between 16-10mm. Similarly, Percentage amount of nitrogen released by each Azotobacter strain in the culture broth ranging between $1.19 \%-5.11 \%$ in an increasing order.
\end{abstract}

Keywords: Rhizobacteria, Azotobacter chroococcum, 16SrRNA Sequencing, Nitrogen-free Agar, Nitrogen-free Broth, Bio-fertilizer

\section{Introduction}

Rhizosphere, a zone of influence around plants roots harbors alot of microoganisms. Among these are the dominant rhizobacteria which prefer living close to vicinity of root plants or surface area and play a crucial role in plant growth [1]. Nitrogen $(\mathrm{N})$ is a key plant nutrient required for plant growth. The elemental nitrogen is in abundant in the atmosphere [2]. However, most tropical soil are deficient in soluble $\mathrm{N}$ and so is the most limiting nutrient element which deficiencies could led to slow growth and reduced crop production [3]. Nitrogen availability in agricultural soil comes either from inputs of atmospheric nitrogen by free living bacteria [4] or from biological nitrogen fixation [5]. Biological Nitrogen Fixation (BNF) is a one way process of converting elemental nitrogen from the atmosphere into plant useable form in the soil. Azotobacter and other group of rhizobacteria are actively involved in the process of BNF, 
secreting nitrogenase enzyme, produces organic acids and siderophores which aid fixation of atmospheric dinitrogen directly into the soil, thus improving the soil fertility. Besides, symbiotic nitrogen fixation, the non-symbiotic nitrogen fixation is also known to be of great agronomic important [1]. BNF is an excellent, economically and environmentally sound approach to replace the use of chemical fertilizer to increase soil fertility and improve plant growth and crop production [6].

\section{Materials and Methods}

\subsection{Sample Collection}

Soil sample from eight different locations within Keffi, Nasarawa State-Nigeria were collected using hand shovel at $20 \mathrm{~mm}$ depth [7] and transfer into sterile polyethylene bag before transported to Microbiology laboratory Nasarawa State University, Keffi for further study.

\subsection{Isolation and Subculture of Azotobacter Species}

Isolation was carried out using a method described by [8]. $1.0 \mathrm{~g}$ of the soil sample was suspended in $9 \mathrm{ml}$ of sterile distilled water in a test-tube. $1 \mathrm{ml}$ was picked and transferred into another test tube containing $9 \mathrm{ml}$ of sterile water. The step was repeated to 10 -fold dilutions. $0.5 \mathrm{ml}$ of the aliquot dilution was picked from the 6th-dilution tube using pipette and spread on prepared Burk's agar plate and incubated at $37^{\circ} \mathrm{C}$ for $48 \mathrm{hrs}$. Discrete colonies were picked and restreaked on Burk's agar slants for further study.

\subsection{Identification of Azotobacter chroococcum}

Cultural and morphological characteristics on Burk's agar were carried out by gram staining method as described [9]. Biochemical test such as methyl red, Voges-proskauer, indole, catalase, oxidase, urease, citrate utilization, motility, starch hydrolysis, gelatin hydrolysis, carbohydrate utilization and cyst formation were also carried out according to the method described in Bergey's Manual of Determinative Bacteriology $9^{\text {th }}$ edition [10-12]. Amplification of the 16SrRNA gene from the extracted genome of the bacteria strain was carried out using the universal primer pairs $27 \mathrm{~F}$ (5'AGAGTTTGATCATGGCTCAG-3') as forward primer and 1492R (5'-GGTTACCTTGTTACGACTT-3') as the reverse primer [13-15]. Full length sequencing of the amplified 16SrRNA gene product (amplicon) of the Azotobater chroococcum was send to Epoch Life science (USA) for purification and Sanger's sequencing as outlined in QIAquick purification protocol (Qiagen, Crawley, UK) [16].

\subsection{The DNA Extraction Procedures}

$500 \mu 1$ overnight culture broth of the bacteria strain was spun at $1000 \mathrm{rpm}$ for $5 \mathrm{~min}$. The pellet was resuspended in $300 \mu \mathrm{l}$ lysis buffer and $2 \mu \mathrm{IRNaseA}$ and later Vortex vigorously for $30-60 \mathrm{sec} .8 \mu \mathrm{l}$ proteinaseK wasa dded to the mixture by pipetting and then IncubateD at $60^{\circ} \mathrm{C}$ for 10minutes and later cools down for 5minutes. Thereafter, $300 \mu \mathrm{l}$ binding buffer was added and vortex briefly before the tube was placed on an ice for 5 minutes and later centrifuge for 5 minutes at $10,000 \mathrm{rpm}$. $40-50 \mu 1$ elution buffer was added into the centre of the column then incubated at room temperature for 1 minute before it was centrifuged at $10,000 \mathrm{~g}$ for 2 minutes and the DNA pellet was stored at $4{ }^{\circ} \mathrm{C}$ or $-20^{\circ} \mathrm{C}$ as outlined in Jena Bioscience extraction protocol [17-18].

\subsection{PCR Amplification of 16SrRNA Gene of the Bacteria Species Isolated}

The 16SrRNA extracted genome DNA of the bacteria strained was amplified using Polymerase chain reaction (PCR) amplification processes by mixing a set of universal primers, 27F (5'-AGAGTTTGATCATGGCTCAG-3') as forward primer and 1492R (5'-GGTTACCTTGTTACGACTT-3')as the reverse primer [13-15]. A typical PCR reaction mixture was prepared by adding $2 \mu \mathrm{l}$ of the template DNA with the $5 \mathrm{X}$ HOT FIREPol Blend Master mix (Solis Biodyne) containing 1.5 $\mu 1$ of forward and $1.5 \mu 1$ reverse primers (BIOMERS, Germany), $5 \mu \mathrm{l}$ of 10X PCR buffer (Solis Biodyne), $1.5 \mu 1 \mathrm{MgCl}_{2}, 2.0 \mu \mathrm{l}$ $\mathrm{mM}$ of deoxynucleoside triphosphates (dNTP) (Solis Biodyne), 1.5 $\mu$ l Taq DNA polymerase enzyme (SolisBiodyne), and $5 \mu \mathrm{l}$ of nuclease free water alongside $5 \mu \mathrm{l}$ cells pellet of the extracted bacteria DNA and the entire reaction mixture was make up to $25 \mu \mathrm{l}$ by total concentration. The PCR reaction mixture tubes were placed on anEppendorf vapo protect thermo cycler machine (Nexus series) to run 30 cycles programme under a given PCR conditions for an initial denaturation at $94^{\circ} \mathrm{C}$ in 2 minutes (30cycles), follow by denaturation at $94^{\circ} \mathrm{C}$ for 45 seconds, annealing at $61^{\circ} \mathrm{C}$ for $1 \mathrm{~min}$, extension at $72^{\circ} \mathrm{C}$ for 1 minute 30 seconds (30cycles) and finally extension at $72^{\circ} \mathrm{C}$ for 5 minutes (1cycle) and hold at $4^{\circ} \mathrm{C}$. The amplified 16SrRNA gene product were run on a $1.5 \%$ agarose gel electrophoresis after staining with ethidium bromide standard solution (aliquot fraction of the PCR product and one DNA ladder were loaded per comb or gel well) for 1hour 30minutes at $80 \mathrm{~V}$. After electrophoresis, distinct DNA bands well separated of the bacteria species were compare with molecular ladder of the standard DNA of the gene size or molecular marker of 1500bp (Solis Biodyne) [19-20].

\subsection{Sequencing of the Amplified 16SrRNA Gene}

Fraction of the amplified genome of the bacteria strains were send (Epoch Life science (USA) for purification according to QIAquick purification protocol described by a study [16]. The purified product was send to Epoch Lifescience (USA) for sequencing (Sanger sequencer machine) and analysis using ABI 3100 soft ware module (version 5.2) [21] (Giovannoni et al.,1990). Thus, the resulted sequenced obtained were compared with the published nucleotide sequences of close related bacteria type strain deposited in the GenBank National Centre for Biotechnology Information (NCBI) database and Ribosomal Database Project via BLAST searches (http://blast.ncbi.nlm.nih.gov/Blast.cgi) [22-23]. 


\subsection{Screening for Nitrogen Fixing Activities by Azotobacter Strain Isolated on Nitrogen-free Agar}

Eight Azotobacter species each was inoculated at the centre of an agar plate and incubated at $37^{\circ} \mathrm{C}$ for $3-5$ days by a method described by [24]. On the third day blue coloured zone producing strains were marked as nitrogen fixers on the agar plate and the colouring zone formed was calculated each by deducting colony diameter from the coloured zone diameter.

Coloured zone index $=\frac{\text { Colony diameter }+ \text { colour zone }}{\text { Colony diameter }}$

\subsection{Quantitative Estimation of the Amount of Nitrogen Content (\%) Released by Azotobacter Strains on Nitrogen-free Culture Broth}

To determine whether these Azotobacter strains previously screened qualitatively are truly nitrogen fixers, they were further inoculated on a Nitrogen-free broth to quantify the amount of nitrogen produced by each strain quantitatively using Kjedahl method described by [25]. Azotobacter strains were inoculated each on a $5 \mathrm{ml}$ conical flask containing nitrogen-free broth (Compositiong/L; $2.5 \mathrm{~g}$ glucose, $0.20 \mathrm{~g}$ $\mathrm{K}_{2} \mathrm{HPO}_{4}, 0.05 \mathrm{~g} \mathrm{KH}_{2} \mathrm{PO}_{4}, 0.1 \mathrm{~g} \mathrm{NaCl}, 0.01 \mathrm{~g} \mathrm{CaCL}, 0.1 \mathrm{~g}$ $\mathrm{MgSO}_{4} .7 \mathrm{H}_{2} \mathrm{O}, 0.005 \mathrm{~g} \mathrm{FeSO}_{4} .7 \mathrm{H}_{2} \mathrm{O}, 0.005 \mathrm{~g} \mathrm{MnSO}_{4} .5 \mathrm{H}_{2} \mathrm{O}$, $0.5 \mathrm{~g} \mathrm{Na}_{2} \mathrm{MoO}_{4} .2 \mathrm{H}_{2} \mathrm{O}, 0.5 \mathrm{~g} \mathrm{CaSO}_{4} .2 \mathrm{H}_{2} \mathrm{O}$ in $250 \mathrm{ml}$ sterile distilled water with $\mathrm{pH}$ adjusted to 7.0 before sterilization). The flasks were then incubated for 9days on a continuous air flows shaker incubator for steady oxygen supply. After the $9^{\text {th }}$ day, fermented cultures broth were harvested, centrifuged at $10,000 \mathrm{rpm}$ for $15 \mathrm{~min}$, to remove dead cells. Using Kjedahl method as described by [25], the total Nitrogen content captured into the culture flask by Azotobacter species each was quantitatively calculated. $10 \mathrm{ml}$ supernatant (filtrate) was mixed with $20 \mathrm{ml}$ concentrated $\mathrm{H}_{2} \mathrm{SO}_{4}(0.01 \mathrm{~N})$ along with $0.1 \mathrm{~g} \mathrm{CuSO}_{4}$ catalyst before digestion. Mixture was heated (digested) at a high temperature $550-600^{\circ} \mathrm{C}$ until white foams are seen. The digest was allowed to cool and the volume make up to $10 \mathrm{ml}$ with sterile water. The $10 \mathrm{ml}$ aliquot was then mixed with $50 \mathrm{ml}$ of $5 \mathrm{~N}$ concentrated $\mathrm{NaOH}$ solution to neutralize $\mathrm{pH}$ and convert probable nitrogen bonds to soluble nitrate. The mixture was condensed by distillation process, and a total of $50 \mathrm{ml}$ distillate (Ammonia gas) was capture into a distillation flask containing $4 \%$ boric acid solution with 4drops of mixed indicator (methyl red and methylene blue) till the solution change from pink to green on completion of the process. Thereafter 2 drops of the mixed indicator was added to the distillate on the flask and titrated against $\mathrm{HCl}$ acid till the colour change from green to slight violet colour. The titre value for each of the experiment performed was recorded and the $\%$ nitrogen content produced was calculated using the formula below.

Calculations

$\%$ Total Nitrogen released on the fermented culture broth is calculated as

$$
\% \mathrm{~N}=\frac{\mathrm{Ts} \times \mathrm{N} \times \mathrm{M} \times \mathrm{Vd} \times 100}{\mathrm{Wi} \times \mathrm{Vb}}
$$

Where,

$\mathrm{T}=$ Titre value $=0.7$, and 0.8

$\mathrm{N}=$ normality of the $\mathrm{HCl}(0.01 \mathrm{~N})$

$\mathrm{M}=$ Mass of nitrogen in the evolved ammonia (14)

$\mathrm{Vd}=$ volume of the digest $=250 \mathrm{ml}$

$\mathrm{V}_{\mathrm{b}}=$ volume of Aliquot filtrate (base) $=50 \mathrm{ml}$

$\mathrm{W}_{1}=$ volume of the broth $(10 \mathrm{~cm}=10 \mathrm{~g})$

\subsection{Statistical Analysis}

Data obtained were analysed using $\mathrm{R}$ Console software (Version3.2.2). Pearson's Chi-square test was used to compare the proportion of activity and ability of the bacterial strains in fixing nitrogen in relation to locations where soil samples was collected. $\mathrm{P}<0.05$ showed no significant difference $\left(\chi^{2}=5.1017, \mathrm{df}=7, \mathrm{P}=0.6475\right)$.

\section{Results}

\subsection{Isolation and Identification of Azotobacter Species}

Cultural, morphology and biochemical characteristics of Azotobacter species isolated is given in Table 1.

Table 1. Cultural morphology and biochemical characteristics of the bacterial species.

\begin{tabular}{|c|c|c|c|c|c|c|c|c|c|c|c|c|c|c|}
\hline \multirow{2}{*}{ Cultural } & \multicolumn{2}{|c|}{ Morphology } & \multicolumn{11}{|c|}{ Biochemical characteristics } & \multirow{2}{*}{ Inference } \\
\hline & G & $\mathbf{S}$ & $\mathbf{C a}$ & $\mathbf{O}$ & $\mathbf{I}$ & MR & $\mathbf{V P}$ & M & CUT & SH & UH & GH & $\mathbf{C F}$ & \\
\hline D/B on Burk'sAgar & - & $\mathrm{C}$ & + & + & - & - & - & + & + & + & - & - & + & Azotobacter sp \\
\hline
\end{tabular}

$\mathrm{G}=$ Gram reaction, $\mathrm{S}=$ shape, $\mathrm{Ca}=$ catalase, $\mathrm{O}=$ Oxidase, $\mathrm{I}=$ indole, $\mathrm{MR}=$ Methylred, $\mathrm{VP}=$ Voges-proskauer, $\mathrm{M}=\mathrm{Motility}, \mathrm{CUT}=\mathrm{Citrate}$ utilization test, $\mathrm{SH}=$ Starch hydrolysis, $\mathrm{UH}=$ Urease hydrolysis, $\mathrm{GH}=$ Gelatin hydrolysis, $\mathrm{CF}=$ Cyst formation, - negative,+ positive $, \mathrm{P}=\mathrm{Polymorphic}, \mathrm{D} / \mathrm{B}=\mathrm{Dark} / \mathrm{brown}$

\subsection{Percentage Occurrence of Azotobacter Species Isolated from Different Locations in Keffi}

Percentage occurrence of the Azotobacter species isolated from different locations within keffi showed that Angwan lambu (AL) and pyanko had the highes $t$ occurrence of Azotobacter isolates with $100 \%$ while High court, Kofar hausa, Old barrack, BCG, pyanko, and Angwan mada had $50 \%$ occurrence as given in Table 2.
Table 2. Percentage occurrence of the bacteria species from different locations in keffi.

\begin{tabular}{lll}
\hline Locations & No. Sample & \%Azotobacterisolates \\
\hline AL & 2 & $2(100)$ \\
HC & 2 & $1(50)$ \\
KH & 2 & $1(50)$ \\
GRA & 2 & $1(50)$ \\
OB & 2 & $1(50)$ \\
BCG & 2 & $1(50)$ \\
\hline
\end{tabular}




\begin{tabular}{lll}
\hline Locations & No. Sample & \%Azotobacterisolates \\
\hline PYANKO & 2 & $2(100)$ \\
AM & 2 & $1(50)$ \\
\hline
\end{tabular}

$\mathrm{AL}=$ Angwan lambu, $\mathrm{KH}=$ Kofar hausa, Pyanko, $\mathrm{HC}=$ Highcourt, $\mathrm{OB}=$ Oldbarrack, $\mathrm{AM}=$ Angwan mada, $\%=$ sPercentage

\subsection{SrRNA Sequenced Gene of the Azotobacter Strain}

16SrRNA gene sequence of the selected Azotobacter strain with hyper activity is given in Figure 1. The sequences obtained was compared with 16SrRNA gene sequences of reference type strain available in the RDP Genbank database (http:11rdp(me.msu.edu/).

\begin{abstract}
GGAACGGGTACACTAGAGTTTGATCCTGGCTCAGAAAACTCAAAACGGGGACCCACAAATTT TTGCCCCGGCCACAAAAAAGCCCAAAGAAGGCCCCCCGTAGTTTTTTTTTACAACCCTACCG AGCCCCGGGGGAACCCCCTTGGTTTTTTTTTTTAACAAATCACCCGAGCGGGGAAAAACACC TTTGGTTTTTTTTTTTAAAACCTTCCCGGGCGGGGAAAACCCCCCTTTTTTTTTTTTTTTTAAAC TTCTAGGGGGGGGGAGGAACCCCCCTTGTTTTTTTTTTTCATCTCTTTCAAGCCCGGGGAAAA CCCCCATTGTTTTTGGGCTTTTATCGTTTGGGGGGGGGAAGAAAACCAACTTGGCTTTTTTTTT TTTAAAAACCTCGAGAGGGGGAGCAGACCTTTTTTTTTTTTTTTTTCACAAACAATCGGAGGG GGAAGGCAAAATTTTTATCTCCTTTTCTTTCCATCAGAGGGGGGGGGGGGGGAAGGCTGAGT GTTTATAAAAGAACAGACGAAGGCTCAAGAAAAAAGATGGAGTTTTTTACTTCATATGCATGT CAGGCCGGCGCAACAGAAATATAGCTTTTAAGAACGACTAACAAGCTACACGACCGAGAGCG AGAAGTGCGGACAGCGTCAGGAACAGATGGGGCAGCTGC
\end{abstract}

Figure 1. Fullength 16SrRNA gene sequence of Azotobacter chroococcum.

\title{
3.4. Rate of Nitrogen Fixing Activity of Azotobacter chroococcum on Nitrogen-free Agar
}

Figure 2 shows the rate of nitrogen fixing activity of Azotobacter strains were the highest coloured zone was observed in Azotobacter species isolated from Angwan lambu (AL) with $16 \mathrm{~mm}$ followed by pyanko with $14 \mathrm{~mm}$, GRA with $12 \mathrm{~mm}$ and the least was observed from isolate from Highcourt $(\mathrm{HC})$ with $10 \mathrm{~mm}$.

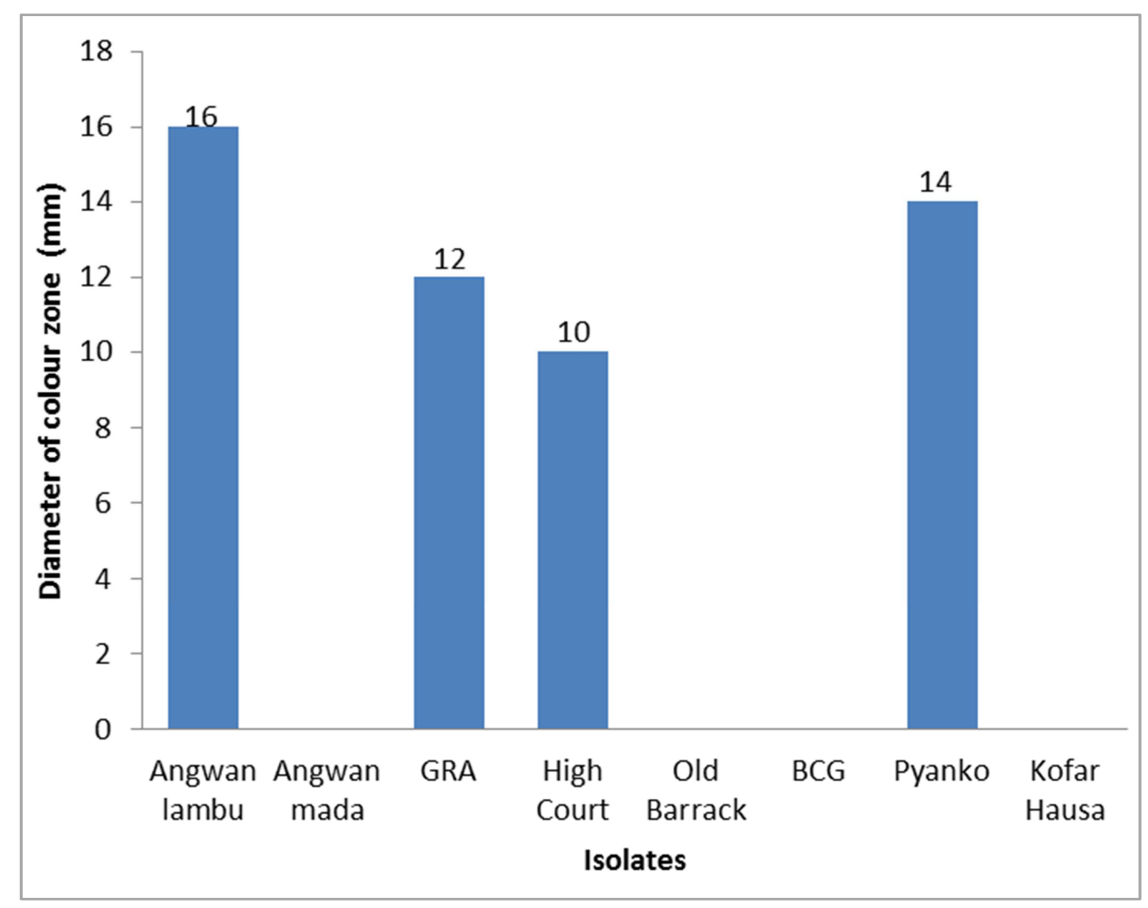

Figure 2. Nitrogen fixing ability of Azotobacter chroococcum on Nitrogen-free agar.

\subsection{Quantitative Estimation of Percentage Amount of Nitrogen Produced by Azotobacter Isolates in the Nitrogen-free Broth}

Figure 3 shows the percentage amount of nitrogen capture by Azotobacter strain were the highest amount was observed in Azotobacter chroococcum isolated from Angwan-lambu (AL) with $5.11 \% \mathrm{~N}$, followed by pyanko with $4.20 \% \mathrm{~N}$ followed by GRA with $3.71 \% \mathrm{~N}$ and Highcourt $(\mathrm{HC})$ with $3.01 \% \mathrm{~N}$ respectively while low amount was observed in Azotobacter isolates from Angwan mada(AM) with $2.31 \% \mathrm{~N}$, followed by Old barrack (OB) with $1.61 \% \mathrm{~N}$, followed by BCG with $1.4 \% \mathrm{~N}$ and the least amount was observed in isolate from Kofar Hausa $(\mathrm{KH})$ with $1.19 \% \mathrm{~N}$ respectively. 


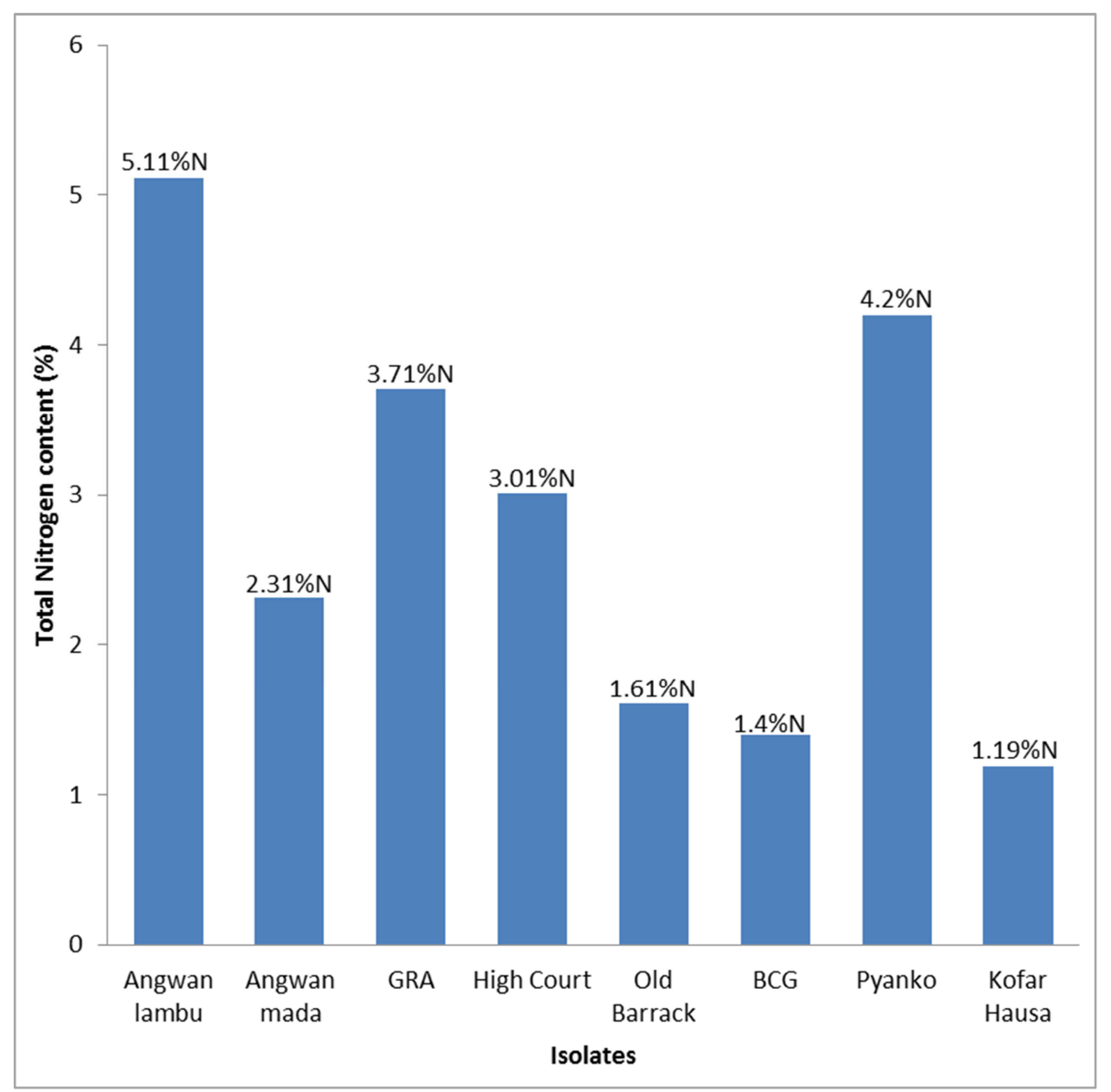

Figure 3. Percentage amount of Nitrogen produced by Azotobacter chroococcum in the Nitrogen-free broth.

\section{Discussion}

Eight Azotobacter species were isolated and their cultural features was observed and identified by various biochemical characteristics and 16SrRNA sequencing analysis. Microscopic examination of the strains showed that they are gram negative, short rod and polymorphic in nature. The 16SrRNA sequence analysis of the selected strain showed maximum similarity of $96 \%$ with Azotobacter chroococcum of the reference type strain. Out of the eight Azotobacter isolates tested on nitrogen freea gar for their nitrogen fixing activities. The highest nitrogen fixing activity by coloured zone formation was observed in Azotobacter species isolated from Angwan lambu (AL) with $16 \mathrm{~mm}$ followed by pyanko with $14 \mathrm{~mm}$, GRA with $12 \mathrm{~mm}$, and the least was observed in isolate from High court (HC) with $10 \mathrm{~mm}$. Thus, the coloured zone formed by Azotobacter strains on nitrogen free agar plate indicates their nitrogen fixing ability and this is due to the secretion of nitrogenase enzyme. Formation of coloured zone by Azotobacter strains is due to secretion of nitrogenase enzyme or production of organic acids by the strains [26], [1]. The coloured zone formed by the strains in relation to locations showed a very high significant difference $\left(\chi^{2}=55.077, \mathrm{df}=7, \mathrm{P}=0.000000001439\right)$.

Similarly, Azotobacter species with the highest percentage nitrogen was observed in Azotobacter strain isolated from
Angwan-lambu (AL) with $5.11 \% \mathrm{~N}$ followed by Pyanko with $4.2 \% \mathrm{~N}$, GRA with $3.71 \% \mathrm{~N}$, High-court (HC) with $3.01 \% \mathrm{~N}$, Angwan mada (AM) with $2.31 \% \mathrm{~N}$, Oldbarrack (OB) with $1.61 \% \mathrm{~N}, \mathrm{BCG}$ with $1.4 \% \mathrm{~N}$ and the least was observed in isolate from Kofar Hausa $(\mathrm{KH})$ with $1.19 \% \mathrm{~N}$ as presented in figure 3 above. Nitrogen fixation occurred due to the production of organic acids or secretion of nitrogenase enzyme by the Azotobacter species in the medium and this is the main principal mechanism of nitrogen fixations [9].

These findings agreed with previous studies [8], [27], [4]. That oxygen supply aid fixation of atmospheric nitrogen into a broth medium devoid of nitrogen source but with little amount of carbon source to be effective. High oxygen supply into the culture medium aid the secretion of nitrogenase enzyme that speed up the process of nitrogen fixation on the medium [9]. However, variability in the percentage nitrogen produced by each Azotobacter strain on the broth medium could be due to climatic factors such as oxygen supply and the nutrient composition of the broth. Statistically there was no significant difference in the amount of nitrogen produced in the medium $\mathrm{P}>0.05$

\section{Conclusion}

The highest nitrogen fixing activity was observed in Azotobacter species isolated from Angwan lambu (AL) with 
$16 \mathrm{~mm}$ followed by pyanko with $14 \mathrm{~mm}$, GRA with $12 \mathrm{~mm}$, and the least was observed in isolate from Highcourt (HC) with $10 \mathrm{~mm}$. Similarly, the highest percentage total nitrogen capture by Azotobacter strain on culture broth was observed in Azotobacter strain isolated from Angwan-lambu (AL) with $5.11 \% \mathrm{~N}$, followed by pyanko with $4.20 \% \mathrm{~N}$ followed by GRA with $3.71 \% \mathrm{~N}$ and Highcourt (HC) with $3.01 \% \mathrm{~N}$ respectively while low amount was observed in Azotobacter isolates from Angwan mada (AM) with $2.31 \% \mathrm{~N}$, followed by Oldbarrack (OB) with $1.61 \% \mathrm{~N}$, followed by $\mathrm{BCG}$ with $1.4 \% \mathrm{~N}$ and the least amount was observed in isolate from Kofar Hausa $(\mathrm{KH})$ with $1.19 \% \mathrm{~N}$ respectively.

Thus, Azotobacter chroococcum isolated from Angwan lambu (AL) is considered a potential candidate for biofertilizer production to enhance plant nutrition especially in soil with low nutrients for an improve crop productivity.

\section{References}

[1] Tilak, K. V. B. R., Ranganayaki, N., Pal, K. K., De, R., Saxena, A. K., Shekhar, Nautiyal, C., Shilpi Mittal, Tripathi, A. K., and Johri, B. N., (2005). Diversity of plant growth and soil health supporting bacteria. Current science, vol. 89, p: 136-143.

[2] Nautiyal SC, Mehta S, (2001). An efficient method for qualitative screening of phosphate-solubilizing bacteria. Current Microbiol. 43: 51-56.

[3] Venkateswarlu, B., Balloli, S. S., Ramakrishna, Y. S., (2007) Organic farming in rain fed Agriculture. Central research institute for dry land agriculture, Hyderabad, p: 88.

[4] Qureshi M. A., Ahmad M. J., Naveed M., Iqbal A., Akhtar N. and Niazi K. H. (2009). Co-inoculation with Mesorhizobium ciceri and Azotobacter chroococcum for improving growth, nodulation and yield of chickpea (Cicerarietinum L.). Soil \& Environ. 28(2), p: 124-129.

[5] Postgate J. (1998). Nitrogen fixation- $3^{\text {rd }}$ Ed., Cambridge University press, Cammbridge, U. K.

[6] Pareek, R. P, Chandra R. and Pareek N. (2002). Role of BNF technology in sustainable agriculture-Proceeding of National Symposium (eds. Masood, A., Chaturvedi S. K and Gurha S. N), Indian Institute of Pulses Research, Kunpur, p. 33-42.

[7] Appanna V D, Gazso L G, StPierre M (1996) Multiple metal tolerance in Pseudomonas fluorescens and its biotechnological significance. J Biotechnol 52: 75-80.

[8] Dobereiner J, (1999). Nonsymbiotic nitrogen fixation in tropical soils. In: Biology and ecology of nitrogen. Proceeding of a Conference National Academy of Science, Washington D. C.

[9] Aquilanti, L., Favilli, F. \& Clementi, F. (2004). Comparison of different strategies for isolation and preliminary identification of Azotobacter from soil samples. Soil. Biol. Biochem., 36: 1475-1483.

[10] Singh S, Chandra R, Patel DK, Rai V (2007). Isolation and characterization of novel Serratia marcescens (AY927692) for pentachlorophenol degradation from pulpand papermill waste. World J Microbial Biotechnol 23: 1747-1754ss.

[11] Sathish Kumar S. R and Bhaskara Rao K. V (2012). A review of Biological Nitrogen Fixation, Molecular and Microbiology
Research Lab, Environmental Biotechnology Division. Int. J. Adv. LifeSci. Vol. 1(2012).

[12] Breed D. M, Gothwal R. K., NigamV. K., Mohan M. K., Sasmal D. and Ghosh P. (2007). Screening of nitrogen fixers from rhizospheric bacterial isolates associated with important desert plants. Appl. Ecol. Environ. Res. 6(2): 101-109.

[13] Lane, D. J. (1991). 16S/23SrRNA sequencing. In: Stackebrandt, E.; Goodfellow, M., (Eds.). Nucleic acid techniques in bacterial systematics. NewYork: John Wiley and Sons p. 115-175.

[14] Turner, G. L. and Gibson, A. H. (1999). Measurement of nitrogen fixation by indirect means. In: Methods for evaluating biological nitrogen fixation, (Bergersen, F. J. ed.), p. 111-138. Chichester: John Wiley \&Sons.

[15] Ahmed I, Yokota A, Fujiwara T (2007). A novel highly boron tolerant bacterium, Bacillus boroniphilus sp. nov., isolated from soil, that requires boron for its growth. Extremophiles 11: $217-224$.

[16] Glyselinck B, Devereux R.; Wilkinson S. S. (2004). Amplification of ribosomal RNA sequences. Molecular microbial ecology manual. 2. ed. Dordrecht; London: Kluwer Academic Publishers v. 3. 01, p. 509-522.

[17] Nishiguchi M. K, Doukakis P, Egan M, Kizirian D, Phillips A, Prendini L, Rosenbaum H. C, Torres E, Wyner Y, Desalle R \&Giribet G (2002). DNA Isolation Procedures. In: De Salle, R.; Giribet, G.; Wheeler, W. C. (eds.). Methods and tools in biosciences and medicine and techniques in molecular systematics and evolution. Switzerland: Birkhauser Verlag Basel, p. 250-287.

[18] Vural H. C., Ozgun D. (2011). An improving DNA isolation method for identification of anaerobic bacteria in human colostrums and faeces samples. J. Med. Genet. Genom., v. 3, n. 5, p. $95-100$.

[19] Devereux R.; Wilkinson S. S. (2004). Amplification of ribosomal RNA sequences. Molecular microbial ecology manual. 2. ed. Dordrecht; London: Kluwer Academic Publishers v. 3. 01, p. 509-522.

[20] Silva M. A. C.; Cavalett A.; Spinner A.; Rosa D. C.; Jasper R. B.; Quecine M. C.; Bonatelli M. L.; Pizzirani-Kleiner A.; Corcao G \&De Souza Lima, A. O. (2013). Phylogenetic identification of marine bacteria isolated from deep-sea sediments of the eastern South Atlantic Ocean. Springer Plus, v.2, p. 127

[21] Giovannoni, S. J., T. B. Britschgi, C. L. Moyer, \& K. G. Field (1990). Genetic diversity in Sargasso Sea bacterioplankton. Nature 345: 60-63.

[22] Nikunjkumar B. D. (2012). Molecular identification of bacteria using 16srRNA sequencing. Gujarat: Gujarat Universityp. 1-62.

[23] Tamura B. H, Ravikumara, S., Kathiresanb, K., Thadedus Maria Ignatiammalc, S., BabuSelvama, M., and Shanthya, S., (2004). Nitrogen-fixing Azotobacters from mangrove habitat and their utility as marine bio-bertilizers. Journal of Experimental Marine Biology and Ecology 312, p: 5-17.

[24] Khin Mya Lwin, Moe M. M, Tar T. T, \& Wai Zin M. A. (2012). Isolation of plant hormone (indole-3-Acetic AcidIAA) producing rhizobacteria and study on their effects on maize seedling. Eng. Jour., Vol.16 (5), Pp. 137-144. 
[25] Association of Analytical Communities, (2016). Official methods of analysis of International, $20^{\text {th }}$ edition. AOAC International, Gaithersburg, Maryland, USA.

[26] Rao, A. V. (2000): Soil biotechnological approaches for sustainable agricultural production in India arid zone Microbiotech 2000, 41st Annual Conference, Association of Microbiologists of India, 6 p.
[27] Stewart, W. D. P (2006). NitrogenFixationinPlants. Athlone Press, London Stotzky, G.: Activity, ecology, and population dynamics of microorganisms in soil. CRCCrit. Rev. Microbiol.,2,59-137. 